\title{
New digenetic trematode parasite Masenia lucknowensis sp. nov. (Trematoda: Maseniidae) from fresh water fishes of Uttar Pradesh (India)
}

\section{Satish Chandra and A. M. Saxena*}

Department of Zoology. University of Lucknow. Lucknow-226 007, U.P. India. *Email: anandmsaxena@rediffmail.com.

\begin{abstract}
Genus Masenia Chatterji, 1933 (Trematoda: Maseniidae Yamaguti, 1954) is one of the most important digenean trematode parasite with wide geographic distribution in the world. The purpose of the present study was to describe morphological and morphometrical characteristics of digenetic trematodes. The present study was carried out in fresh water fish fauna of River Gomti,

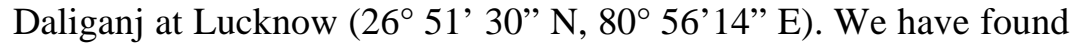
that fresh water fishes heavily infected with various helminthes parasites. We have recovered large number of digenean parasites which belong to genus viz. Masenia Chatterji, 1933. During the survey (2012, Daliganj Lucknow) of fresh water digenetic trematode parasites, collected three different species of the genus Masenia, out of these one is new species, another are redescribed to show certain variation, the new parasite was obtain from the intestine of fish Mystus vittatus (Bloch, 1794) (Actinopterygii: Bagridae).
\end{abstract}

Keywords: Digenea; Fresh water fishes; Mystus vittatus; Parasite; India.

\section{Introduction}

Digeneans are important group of helminth parasites, usually invade gastrointestinal tract of fresh water piscian hosts. Fishes are important due to its high nutritional value and economic value, thus we can call it gold coin of the aquatic environment. Fresh water fishes are the common host for various species of digenetic trematode parasites in Lucknow (Uttar Pradesh), abundantly found in River Gomti and different ponds of Lucknow. Majority of freshwater fishes carry heavy
Received April 5, 2016

Accepted June 14, 2016

Released June 30, 2016

Open Acess Full Text Article

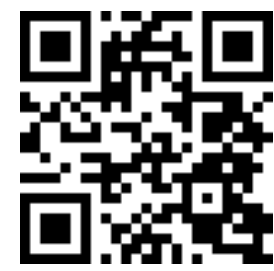

ORCID

() 0000-0001-7239-756X

Satish Chandra

(1) 0000-0001-5596-8738

A. M. Saxena infection of digenean parasites which cause deterioration in the food value of fish and may even result in their mortality (Yadav et al., 2010). These parasites which are transmitted to human beings only through fishes due to weak association of host and parasites called zoonotic parasites. These parasites use the fishes as their shelter, food and destruct more or less each and every organ resulting in pathogenic effects (Lilley et al., 1992). These interfere with the nutrition; metabolism and secretary function of alimentary canal, damage nervous system and even upset the normal 
reproduction of the hosts (Rahman et al., 1998a, b). In this paper we are adding to a new species of Masenia collected from the fresh water fish Mystus vittatus (Bloch, 1794) (Actinopterygii: Bagridae). Many researcher from all over the world collected more efficient and adequate knowledge about the genus Masenia. During the helminth parasite survey, we have found 30 infected fish with this genus; one form is new to science while other forms are rediscribed. The present investigation was undertaken to reveal the taxonomical status of the genus Masenia Chatterji, 1933.

\section{Materials and methods}

The host fishes were collected in the month of January to December, 2012 from the river Gomti, Daliganj at Lucknow ( $\left.26^{\circ} 51^{\prime} 30^{\prime \prime} \mathrm{N}, 80^{\circ} 56^{\prime} 14^{\prime \prime} \mathrm{E}\right)$. During the examination of the fresh water fishes specimens for above genus, we were recovered fish Mystus vittatus (Bloch, 1794). These specimens were collected and identified by standard fish books (Srivastava, 2007) and cut open and thoroughly examined for digenetic helminth parasites, were separated in Petri dish containing normal saline solution (0.89 g $\mathrm{NaCl} / 100 \mathrm{~mL}$ distilled water). The parasite were flattened with slight pressure of cover glass and fixed in A.F.A. fixative (50\% alcohol, formalin and acetic acid in ratio of 100: 6: 2.5). They were stained in acetoalum carmine, differentiated in acid alcohol and dehydrated through ascending grade of ethanols. These were cleared in xylol and mounted in Canada balsam or DPX. The diagrams were made with the help of camera Lucida. All the measurements in millimeters: unless otherwise stated.

\section{Results}

\section{Description}

Family: Maseniidae Yamaguti, 1954

Subfamily: Maseniinae Chatterji, 1933

Genus: Masenia Chatterji, 1933

Masenia lucknowensis sp. nov. (Figure 1.1 and 1.2)
Body elongated, spinose with rounded anterior and posterior ends, 1.52$1.56 \mathrm{~mm}$ long, $0.55-0.58 \mathrm{~mm}$ wide. Oral sucker terminal, funnel shape with circumoral crown of spines, $0.14-0.15 \mathrm{~mm}$ long, $0.12-0.14 \mathrm{~mm}$ wide. Pre-pharynx short, $\quad 0.020-0.022 \mathrm{~mm}$ long, 0.025$0.027 \mathrm{~mm}$ wide. Pharynx globular, muscular $\quad 0.04-0.05 \mathrm{~mm}$ long, 0.045$0.05 \mathrm{~mm}$ wide. Oesophagus short, $0.020-$ $0.022 \mathrm{~mm}$. Intestinal caeca extending up to hind end of anterior testis. Ventral sucker sub-spherical, median, pre-equatorial, larger than oral sucker, $0.15-0.16 \mathrm{~mm}$ long, $0.18-0.19 \mathrm{~mm}$ wide, at $0.45-0.50 \mathrm{~mm}$ from anterior extremity. Excretory pore terminal, excretory bladder saccular. Genital pore sub-median, at the level of oral sucker on the right side, at $0.13-0.15 \mathrm{~mm}$ from anterior extremity. Testes entire, unequal, tandem. Anterior testis oval, pre-equatorial, $0.14-0.15 \mathrm{~mm}$ long, $0.23-0.24 \mathrm{~mm}$ wide, at $0.70-0.72 \mathrm{~mm}$ from anterior extremity. Posterior testis sub-spherical, $0.17-0.18 \mathrm{~mm}$ long, $0.20-0.22 \mathrm{~mm}$ wide, at $0.69-0.71 \mathrm{~mm}$ from anterior extremity. Cirrus sac elongated, tubular extending from hind end of ventral sucker up to hind end of oral sucker, 0.60-0.62 mm long, 0.15-0.16 mm wide. Vesicula seminalis bipartite, posterior part oval, large, 0.18-0.19 mm long, 0.13$0.14 \mathrm{~mm}$ wide; anterior part small, $0.12-$ 0.14 mm, 0.08-0.09 mm wide. Parsprostatica long, tubular, 0.15-0.16 mm long, $0.020-0.022 \mathrm{~mm}$ wide, surrounded by large number of prostate gland cells. Ovary entire, sub-median, spherical, pre-testicular, pre-equatorial, $0.13-0.14 \mathrm{~mm}$ long, $0.15-$ $0.16 \mathrm{~mm}$ wide, at $0.61-0.63 \mathrm{~mm}$ from anterior extremity. Receptaculum seminis small, oval present between ovary and anterior testis $0.05-0.06 \mathrm{~mm}$ long, 0.08$0.09 \mathrm{~mm}$ wide. Vitellaria large, follicular, irregular, extending from middle region of ventral sucker up to hind end of anterior testis. Uterus arises from ootype runs forward to open at genital pore occupying most of post-acetabular space. Uterine coils extra-caecal and intra-caecal. Eggs oval, operculated $0.05-0.08 \mathrm{~mm}$ long, 0.04$0.07 \mathrm{~mm}$ wide. 

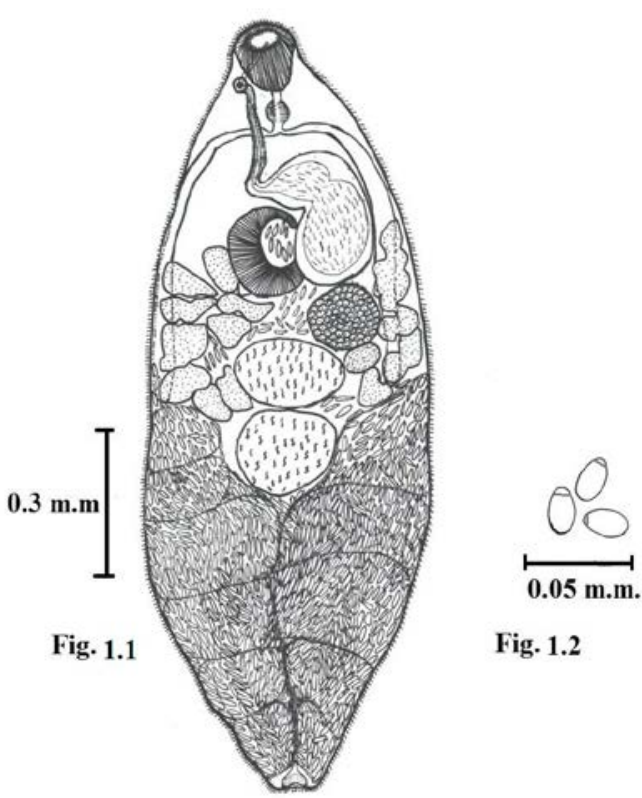

Fig. 1.2

Masenia lucknowensis sp. nov.

Figure 1. Masenia lucknowensis sp. nov.; 1.1. Ventral view of adult; 1.2. Eggs.

Host: Mystus vittatus (Bloch, 1794)

Location: Stomach

Locality: Lucknow

Prevalence: Two specimens from one host out of ten examined.

Discussion: The Present form referred to the genus Masenia Chatterji, 1933. There are following species viz. Masenia collata Chatterji, 1933; Masenia dayali (Gupta \& Puri, 1984) nec Gupta, 1955; Masenia fossilisi Gupta, 1953; Masenia vittatusia Agarwal, 1963; Masenia gomtia Agarwal, 1963; Masenia ritai Sircar and Sinha, 1970; Masenia upeneusi Gupta and Puri,1984; Masenia carangai Gupta \& Tandon, 1985 and Masenia orissai Gupta \& Tandon, 1985; Masenia chauhani Maurya, Agarwal \& Singh, 1989; Masenia jaunpurensis Maurya \& Singh, 2004a; Masenia hanumanthai Pandey and Govind, 2009 are known so far.

The present form differs from all the known species except Masenia collata, Masenia dayali, Masenia vittatusia and Masenia chauhani in having ovary preequatorial and extension of vitellaria.
Present form differs from Masenia collata and Masenia chauhani in presence of excreatory bladder saccular instead of tubular and from Masenia dayali in presence of spherical ovary instead of lobed ovary and from Masenia vittatusia in presence of pre-pharynx and operculated eggs instead of absence of pre-pharynx and non-operculated eggs and in relative shape and size of the various organs. Thus on account of above-mentioned differences as against all those described earlier, the present form deserves the status of a new species with the specific name Masenia lucknowensis sp. nov.

\section{Redescription:}

Masenia collata Chatterji, 1933 (Figures 2.1 and 2.2)
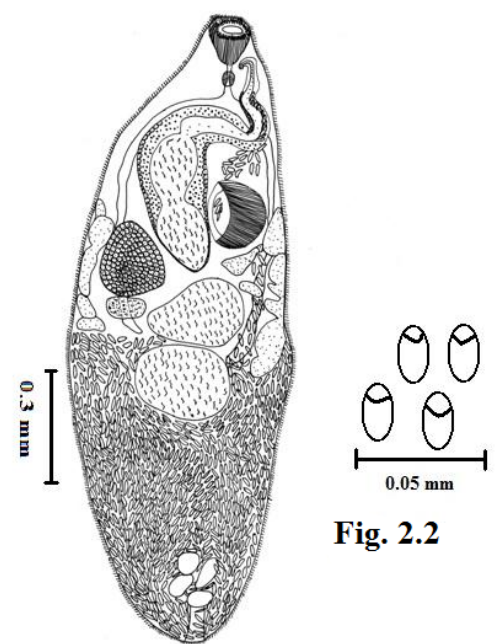

Fig. 2.2

Fig. 2.1

\section{Masenia collata Chatterji, 1933}

Figure 2. Masenia collata Chatterji, 1933; 2.1. Ventral view of adult; 2.2. Eggs.

Body elongated, spinose with rounded anterior and posterior ends, 1.61$1.77 \mathrm{~mm}$ long, $0.53-0.58 \mathrm{~mm}$ wide. Oral sucker terminal, funnel shape with circumoral crown of spines, $0.12-0.13 \mathrm{~mm}$ long, $\quad 0.13-0.15 \mathrm{~mm}$ wide. Pre-pharynx short, 0.02-0.04 mm long, 0.015-0.017 mm wide. Pharynx globular, muscular 0.035$0.04 \mathrm{~mm}$ long, $\quad 0.036-0.037 \mathrm{~mm}$ wide. 
Oesophagus short $0.030-0.031 \mathrm{~mm}$ long, $0.020-0.021 \mathrm{~mm}$ wide. Intestinal caeca extending up to anterior level of anterior testis. Ventral sucker large, spherical, submedian, pre-equatorial, larger than oral sucker, $0.17-0.20 \mathrm{~mm}$ long, $0.15-0.19 \mathrm{~mm}$ wide, at $0.53-0.58 \mathrm{~mm}$ from anterior extremity. Excretory pore terminal, excretory bladder is tubular. Genital pore lying at the level of posterior end oral sucker, at $0.13-0.16 \mathrm{~mm}$ from anterior extremity. Testes median, entire, subequal, directly tandem. Anterior testis pear shape $0.28-0.29 \mathrm{~mm}$ long, $0.20-0.21 \mathrm{~mm}$ wide, at $0.83-0.86 \mathrm{~mm}$ from anterior extremity. Posterior testis sub-spherical, $0.28-0.29 \mathrm{~mm}$ long, $0.21-0.22 \mathrm{~mm}$ wide, at $0.75-0.78 \mathrm{~mm}$ from posterior extremity. Cirrus sac elongated, tubular extending from hind end of ventral sucker up to hind end of oral sucker, $0.45-0.48 \mathrm{~mm}$ long, $0.18-0.20 \mathrm{~mm}$ wide. Vesicula seminalis bipartite, Posterior part oval, $0.20-0.22 \mathrm{~mm}$ long, $0.18-$ $0.19 \mathrm{~mm}$ wide; anterior part $0.18-0.19 \mathrm{~mm}$ long, $0.13-0.14 \mathrm{~mm}$ wide. Parsprostatica tubular sinus, $0.36-0.37 \mathrm{~mm}$ long, 0.05$0.06 \mathrm{~mm}$ wide, surrounded by large number of prostate gland cells. Ovary entire, submedian, sub-spherical, pre-testicular, preequatorial, $\quad 0.19-0.21 \mathrm{~mm}$ long, $0.17-$ $0.19 \mathrm{~mm}$ wide, at $0.75-0.78 \mathrm{~mm}$ from anterior extremity. Receptaculum seminis small, oval present just below ovary, 0.063$0.080 \mathrm{~mm}$ long, $0.010-0.013 \mathrm{~mm}$ wide. Vitellaria large follicular, irregular, extending from middle region of ventral sucker up to hind end of anterior testis. Uterus arises from ootype runs forward to open at genital pore occupying most of pre and post-acetabular space. Uterine coils extra-caecal and intra-caecal. Eggs oval, operculated $0.025-0.028 \mathrm{~mm}$ long, 0.015 $0.018 \mathrm{~mm}$ wide.

Host: Mystus vittatus (Bloch, 1794)

Location: Stomach

Locality: Lucknow

Prevalence: Two specimens from one host out of ten examined.

Discussion: The present form closely resembles with the species Masenia collata Chatterji, 1933 in presence of tubular excretory bladder, extension of vitelline glands but differs from in position of genital pore, shape, size of ovary, testes, receptaculum seminalis and in relative shape and size of various organs. These differences are considered as individual specific variations within the species.

\section{Redescription:}

Masenia dayali (Gupta \& Puri, 1984) nec Gupta, 1955 (Figure 3.1 and 3.2)

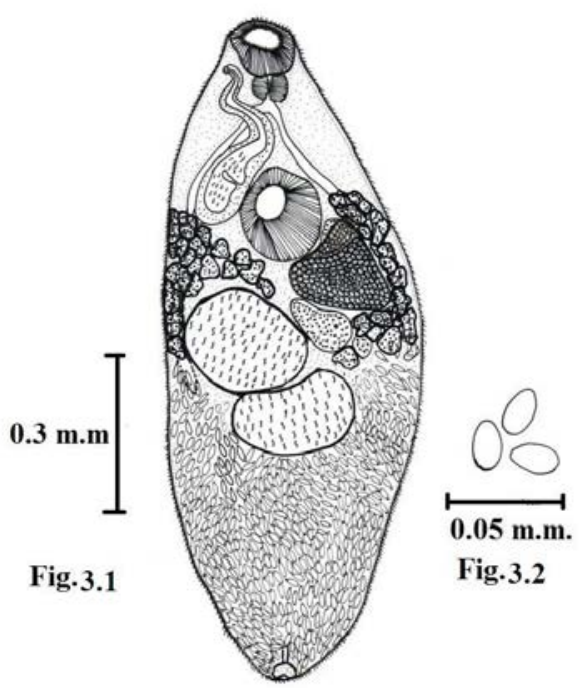

Masenia dayali Gupta, 1954

Figure 3. Masenia dayali. 3.1. Ventral view of adult; 3.2. Eggs.

Body elongated, spinose with rounded anterior and posterior ends, 1.22$1.23 \mathrm{~mm}$ long, $0.50-0.52 \mathrm{~mm}$ wide. Oral sucker terminal, funnel shape with circumoral crown of spines, $0.10-0.12 \mathrm{~mm}$ long, $\quad 0.11-0.12 \mathrm{~mm}$ wide. Pre-pharynx absent. Pharynx globular, muscular 0.05$0.06 \mathrm{~mm}$ long, $\quad 0.06-0.07 \mathrm{~mm}$ wide. Oesophagus very short. Intestinal caeca extending up to hind end of anterior testis. Ventral sucker spherical, median, preequatorial, larger than oral sucker, 0.16$0.17 \mathrm{~mm}$ long, $0.15-0.16 \mathrm{~mm}$ wide, at 0.35 $0.37 \mathrm{~mm}$ from anterior extremity. Excretory pore terminal, excretory bladder saccular. Genital pore sub-median, at the level of posterior to oral sucker, at $0.12-0.14 \mathrm{~mm}$ 
from anterior extremity. Testes entire, unequal, directly diagnal. Anterior testis oval, equatorial, larger than posterior testis, $0.20-0.22 \mathrm{~mm}$ long, $0.23-0.24 \mathrm{~mm}$ wide, at $0.60-0.63 \mathrm{~mm}$ from anterior extremity. Posterior testis concave shape, 0.13$0.14 \mathrm{~mm}$ long, $0.24-25 \mathrm{~mm}$ wide, at 0.51 $0.53 \mathrm{~mm}$ from posterio extremity. Cirrus sac elongated, tubular extending from mid level of ventral sucker up to mid level of oral sucker, $0.34-0.37 \mathrm{~mm}$ long, 0.08$0.10 \mathrm{~mm}$ wide. Vesicula seminalis bipartite, posterior part, 0.065-0.068 mm long, 0.045$0.0 .047 \mathrm{~mm}$ wide; anterior part, 0.08$0.09 \mathrm{~mm}, \quad 0.055-0.057 \mathrm{~mm}$ wide. Parsprostatica long, tubular, 0.010$0.011 \mathrm{~mm}$ long, $0.010-0.011 \mathrm{~mm}$ wide surrounded by large number of prostate gland cells. Ovary entire, sub-median, triagular, pre-testicular, pre-equatorial, $0.17-0.19 \mathrm{~mm}$ long, $0.15-0.16 \mathrm{~mm}$ wide, at $0.50-0.53 \mathrm{~mm}$ from anterior extremity. Receptaculum seminis small, cone shape present between ovary and anterior testis, 0.13-0.14 mm long, 0.08-0.09 mm wide. Vitellaria large, follicular, irregular, extending from middle region of ventral sucker up to hind end of anterior testis. Uterus arises from ootype runs forward to open at genital pore occupying most of post-acetabular space. Uterine coils extracaecal and intra-caecal. Eggs oval, nonoperculated $0.025-0.028 \mathrm{~mm}$ long, 0.015 $0.018 \mathrm{~mm}$ wide.

Host: Mystus vittatus (Bloch, 1794)

Location: Stomach

Locality: Lucknow

Prevalence: Two specimens from one host out of ten examined.

Discussion: The present form closely resembles with the species Masenia dayali Gupta, 1954 in having shape of excretory bladder, extension of vitellaria but differs from in the size of the receptaculum seminis, in the extension of vitellaria, shape, size and position of ovary, testes, receptaculum seminalis and in relative shape and size of the various organs. These differences are considered as individual specific variations within the species.

\section{Acknowledgements}

Authors are thankful to Head, Department of Zoology, University of Lucknow, Lucknow, for providing laboratory facility and Prof K. C. Pandey, ex-Vice Chancellor, Meerut University and ex-Head, Department of Zoology, University of Lucknow for giving important suggestions during the work.

\section{Conflict of interest statement}

Authors declare that they have no conflict of interests.

\section{References}

Agarwal, V. On three trematode from the intestine of a fresh water fish Mystus vittatus (Bloch) from Lucknow. Indian Journal of Helminthology, v. 15, no. 2, p. 138-147, 1963.

Chatterji, R. C. On the trematode parasites of a rangoon siluroid fish Clarias batrachus (Linnaeus 1785). Bulletin of the Academy of Sciences Allahabad, v. 3, p. 36-40, 1933.

Gupta, S. P. Trematode parasites of fresh water fishes. Indian Journal of Helminthology, v. 1, p. 1-80, 1953.

Gupta, V.; Jain, N. Rediscription of Masenia collate Chatterji, 1933 from a fresh water fish Heteropneustis fossilis (Bloch) from Lucknow and synonymy with $M$. ritai. Indian Journal of Helminthology, p. 75-79, 1990.

Lilley, J. H.; Phillips, M. J.; Tonguthai, K. A review of epizootic ulcerative syndrome (EUS) in Asia. Bangkok, Thailand: Aquatic Animal Health Research Institute and Network of Aquaculture Center in Asia-Pacific, 1992.

Maurya, A. K.; Agarwal, G. P.; Singh, S. P. N. On a new species Masenia chauhani sp. nov. (Digenea: Maseniidae) from the intestine of a fresh water fish Rita rita (Ham.) from Varanasi (U.P.). Indian Journal of Helminthology, v. 41, no. 2, p. 149-151, 1989.

Maurya, N. K.; Singh, H. S. Occurrence of Masenia dayali Gupta, 1955 and Masenia jaunpurensis sp. nov. (Trematoda: Maseniidae) in Channa spp. at Jaunpur, India. Journal of Experimental Zoology, v. 7, no. 1, p. 97-98, 2004a.

Maurya, N. K.; Singh, H. S. New digenetic trematode, Masenia jaunpurensis from fresh water fish, Channa gachua (Ham.) from River Gomti, Jaunpur, India. Journal of 
Experimental Zoology, v. 7, no. 1, p. 169-171, 2004b.

Pandey, B.; Govind, H. Occurrence of Masenia hanumanthai sp. nov. in fresh water fish Rita rita (Ham.) from Varanasi, India. In: Pandey, B. N.; Trivedi, S. P.; Jaiswal, K.; Sethi, N. K. (Eds.). Fish and fisheries. New Delhi: Sarup Book Publishers, 2009.

Rahman, M. R.; Prvez, M. A.; Jahan, M. S.; Sarker, M. M. Histopathology of Bellamya bengalensis (Lamarck) by larval helminth. Univ. J. Zool. Rajshahi Univ. v. 17, p. 19-27, 1998a.

Rahman, M. R.; Parween, S.; Ara, H. A brief report on two helminth endoparasites from Mastacembelus armatus (Lacepede). Univ. J. Zool. Rajshahi Univ. v. 17, p. 75-77, 1998b.
Singh, P.; Singh, S. S.; Singh, J.; Gupta, R. C. New species of digenetic trematode of the genus Masenia from a catfish Channa gachua from Gomati River, Jaunpur. Journal of Nature Conservation, v. 18, no. 2, p. 417-420, 2006.

Sircar, M.; Sinha, D. P. On Masenia ritai n. sp. (Maseniidae: Trematoda) from the intestine of Rita rita. Indian Journal of Helminthology, v. 22, no. 1, p. 23-28, 1970.

Srivastava, G. J. Fishes of Uttar Pradesh and Bihar. 20 ed. Varanasi: Vishwavidyalaya Prakashan, 2007.

Yadav, S.; Chandra, S.; Saxena, A. M. An ecological study on digenetic trematode parasite of channa punctatus of Lucknow, Uttar Pradesh. Lucknow journal of Science, v. 7, no. 2, p. 1-8, 2010.

License information: This is an open-access article distributed under the terms of the Creative Commons Attribution License, which permits unrestricted use, distribution, and reproduction in any medium, provided the original work is properly cited. 